\title{
Toxicity of essential oils from leaves of Piperaceae species in rice stalk stink bug eggs, Tibraca limbativentris (Hemiptera: Pentatomidae)
}

\author{
Toxicidade de óleos essenciais das folhas de espécies de Piperaceae sobre ovos de \\ percevejo do colmo do arroz, Tibraca limbativentris (Hemiptera: Pentatomidae)
}

\author{
Diones Krinski ${ }^{*}$, Luís Amilton Foerster ${ }^{2}$
}

\author{
'Universidade do Estado de Mato Grosso/UNEMAT, Departamento de Ciências Biológicas, Tangará da Serra, MT, Brasil \\ ²Universidade Federal do Paraná/UFPR, Departamento de Zoologia, Curitiba, PR, Brasil \\ *Corresponding author: dioneskrinski@gmail.com \\ Received in May 22, 2016 and approved in September 14, 2016
}

\begin{abstract}
Tibraca limbativentris to is an important rice pest and occurs in all rice-growing regions of Latin America. The control this insect is accomplished with synthetic chemical insecticides, however, new approaches are needed to reduce risks to the environment, to the natural enemies and also to avoid the onset of insecticides resistance. This study was designed to assess the toxicity of essential oils (EOs) from leaves of Piper aduncum, P. gaudichaudianum, P. malacophyllum, P. marginatum and P. tuberculatum (Piperaceae) on rice stalk stink bug eggs, T. limbativentris. Essential oils were extracted with steam distillation and dilutions were made for bioassays at concentrations of $0.25 ; 0.5$; $1.0 ; 2.0$ and $4.0 \%$. Essential oils from all species of Piperaceae displayed ovicidal activity. The LC $_{50}$ values indicated that both younger and older eggs were susceptible to these oils. Ovicidal activity is related to the potential toxicity of several compounds, especially dilapiolle, myristicin, cubebene, a-guaiene, longifolene, prezizane, spathulenol, sabinene and $\delta$-2-carene. Thus, EOs tested showed promising results for use as biorational botanical insecticides.
\end{abstract}

Index terms: Piper aduncum; Piper gaudichaudianum; Piper malacophyllum; Piper marginatum; Piper tuberculatum.

\begin{abstract}
RESUMO
Tibraca limbativentris é uma importante praga do arroz e ocorre em todas as regiões de cultivo de arroz da América Latina. O controle destes inseto é realizado com inseticidas químicos sintéticos, no entanto, novas abordagens são necessárias para reduzir os riscos para o ambiente, inimigos naturais, e também para evitar o aparecimento da resistência aos inseticidas. Este estudo foi concebido para avaliar a toxicidade dos óleos essenciais (OEs) das folhas de Piper aduncum, P. gaudichaudianum, P. malacophyllum, P. marginatum e P. tuberculatum (Piperaceae) sobre ovos do percevejo do colmo do arroz, T. limbativentris. Os OEs foram extraídos por arraste de vapor d' agua e a partir destes foram feitas diluições nas concentrações de 0,$25 ; 0,5 ; 1,0 ; 2,0$ e 4,0\% para os bioensaios. Os OEs de todas as espécies de Piperaceae apresentaram atividade ovicida. Os valores de $\mathrm{CL}_{50}$ indicaram que tanto os ovos mais jovens quantos os mais velhos foram suscetíveis aos diferentes óleos. Esta atividade ovicida pode estar relacionada com a toxicidade dos vários compostos encontrados em cada OE, como o dilapiol, miristicina, cubebeno, a-guaieno, longifoleno, prezizano, espatulenol, sabineno e $\delta$-2-careno. Assim, os OEs testados mostraram resultados promissores para serem utilizados como inseticidas vegetais.
\end{abstract}

Termos para indexação: Piper aduncum; Piper gaudichaudianum; Piper malacophyllum; Piper marginatum; Piper tuberculatum.

\section{INTRODUCTION}

The rice stalk stink bug, Tibraca limbativentris Stål, occurs in all rice-growing regions of Latin America, where it is an important pest causing significant losses during the pre-flowering and grain filling stages (Krinski; Foerster, 2016). The occurrence of this pest has increased due to greater crop acreage, and favorable climatic and agronomic practices (Martins; Grützmacher; Cunha, 2004; Rampelotti et al., 2007). Currently, the control of T. limbativentris is accomplished with synthetic chemical insecticides (Rampelotti-Ferreira et al., 2010; Souza et al., 2009).
However, new approaches are needed to reduce risks to the environment and natural enemies and reduce the onset of insecticide resistance (Petroski; Stanley, 2009; RampelottiFerreira et al., 2010). Biopesticides with a different mode of action from that of conventional neurotoxic insecticides can reduce the risk of resistance (Olson, 2015). Additionally, they may be safer and environmentally more acceptable (Sahayaraj, 2014). Thus, strategies of insect management should include alternatives to conventional insecticides.

An alternative approach for the control of this stink bug is the use of botanical insecticides with low 
toxicity and short persistence in the environment (Costa; Silva; Fiuza, 2004). In this context, plants of the family Piperaceae may be a promising alternative for the control of pests in general because they possess substances with high insecticide potential (Barbosa et al., 2012; Estrela et al., 2006; Fazolin et al., 2007). Other plant families have been investigated for their ovicidal properties, especially for insect vectors of disease such as triatomine bugs (Reduviidae) (Carneiro; Pereira; Galbiati, 2011; Laurent et al., 1997). However, few studies have been conducted on the ovicidal effect of Piperaceae on either chewing or sucking insects (Scott et al., 2008). Therefore, due to the importance of identifying alternate environmentally sound methods for agricultural pest control, we sought to determine the toxicity of essential oils (EOs) from leaves of five species of Piperaceae on Tibraca limbativentris eggs.

\section{MATERIAL AND METHODS}

The insects used on the bioassays were obtained from a colony of $T$. limbativentris maintained in the Entomology Laboratory of Embrapa Rice and Beans located in Santo Antônio de Goiás, Goiás State, Brazil (16 $30^{\circ} 12.25^{\prime \prime} \mathrm{S} 49^{\circ} 16^{\prime} 55.28^{\prime \prime} \mathrm{W}-834 \mathrm{~m}$ ).

\section{Essential oils extraction}

To obtain the EOs we used leaves of Piper marginatum L. (707'43.56”S 55²3'22.09”'W - 231 $\mathrm{m})$ and Piper malacophyllum Prels., collected at Fazenda Florentino, Novo Progresso, ( $7^{\circ} 06^{\prime} 56.31^{\prime \prime} \mathrm{S}$ $55^{\circ} 24^{\prime} 22.19^{\prime \prime} \mathrm{W}-210 \mathrm{~m}$ ), Pará State, Brazil; Piper aduncum L. and Piper tuberculatum Jacq., collected at Tangará da Serra, (both 4³7'29.32”S 57²9'09.10”W - 385 m), Mato Grosso State, Brazil; and Piper gaudichaudianum Kuntze collected near Tingui Park, Curitiba, (25'23'30”S $49^{\circ} 18^{\prime} 22^{\prime \prime} \mathrm{W}-908 \mathrm{~m}$ ) Paraná State. The Piper spp. were identified by botanist Dra. Micheline Carvalho-Silva at the University of Brasilia (UnB), and herbarium specimens of these species have been deposited at the State University of Mato Grosso, Campus of Tangará da Serra (UNEMAT/ CUTS) in Herbarium Tangará (TANG) under collection numbers 1738, 1741, 1776, 1778 and 1779.

After leaf collection, the material was taken into a greenhouse for $96 \mathrm{~h}$ at $37{ }^{\circ} \mathrm{C}$ to dry. Then each plant was ground with a mill to obtain powder. The milled material was sent to the Vegetable Ecophysiology Laboratory at the Federal University of Paraná (UFPR), where the oils were extracted by steam distillation. For each oil extraction, $50 \mathrm{~g}$ of vegetable powder were placed in a glass flask $(2 \mathrm{~L})$ containing $1 \mathrm{~L}$ of distilled water. The flask was heated in a heating mantle and boiled for $3 \mathrm{~h}$ to obtain the EOs. The oils were diluted with water to concentrations of $0.25,0.5,1.0,2.0$ and $4.0 \%$, and $5 \%$ Tween $^{\circledR} 20$ was added to emulsify the oil.

\section{Chromatographic analysis}

Chromatographic analysis was performed in the Department of Molecular Sciences at the Federal Rural University of Pernambuco (UFRPE), Brazil. The EOs were analyzed by Gas Chromatography/Mass Spectrometry (GC/MS) $\left(60-240{ }^{\circ} \mathrm{C}\right.$ at $3{ }^{\circ} \mathrm{C}$ min rate) in a Varian $431-\mathrm{GC}$ coupled to a Varian 220-MS instrument using a fusedsilica capillary column ( $30 \mathrm{~m}$ x $0.25 \mathrm{~mm}$ i.d. x $0.25 \mu \mathrm{m})$ coated with DB-5. The injector and detector temperatures were 250 and $260^{\circ} \mathrm{C}$, respectively. Helium was used as a carrier gas at a flow rate of $1.5 \mathrm{~mL} / \mathrm{min}$; injection was in the split mode (1:50), and the injection volume was 1.0 $\mu \mathrm{L}$. MS spectra were obtained using electron impact at $70 \mathrm{eV}$ with a scan interval of $0.5 \mathrm{~s}$ and mass range from 40 to $550 \mathrm{~m} / \mathrm{z}$. The initial identification of components of the EO was carried out by comparison with previously reported values of retention indices, obtained by coinjection of oil samples and C11-C24 linear hydrocarbons and calculated according to the equation of Van den Dool and Kratz (1963). Subsequently, the MS acquired for each component was matched with those stored in the Wiley/ NBS mass spectral library of the GC-MS system and with other published mass spectral data (Adams, 2007).

\section{Bioactivity of EOs on Tibraca limbativentris eggs}

To evaluate the activity of EOs from Piperaceae leaves on $T$. limbativentris eggs of different ages, the bioassays were performed by immersion of eggs in dilutions of the extracts. The experimental design was completely randomized, using egg masses that were 24 , 48, 72 and 96 h old (HO). Each treatment consisted of 10 replicates, and each replicate contained one egg mass with 10 eggs. The eggs were immersed in one of five oil concentrations $(0.25,0.5,1.0,2.0$ and $4.0 \%)$ or the two control treatments (distilled water, $5 \%$ Tween ${ }^{\circledR} 20$ solution), totaling 28 treatments for each Piper species used. All egg masses from each treatment were immersed for $10 \mathrm{sec}$ in each concentration and after this time the eggs were placed on filter paper to dry at room temperature. The eggs were placed in Petri dishes $(10 \mathrm{~cm} \times 1 \mathrm{~cm})$ with a moistened paper towel. The treatments were maintained at $25.7 \pm$ $3.0^{\circ} \mathrm{C}( \pm \mathrm{SD}), 53.6 \pm 10.8 \%$ relative humidity $( \pm \mathrm{SD})$ and a photoperiod of 14:10 L:D. The bioassays were evaluated daily until hatching nymphs attained the second instar, at which time we tabulated the percentage of hatched eggs. 


\section{Statistical analysis}

For statistical analysis we used results obtained $240 \mathrm{~h}(10 \mathrm{~d})$ after treatment in each EO. After this time no hatching of T. limbativentris was recorded. The treatment effects were studied by a generalized linear model (GLM) and by analysis of deviance, considering a statistical model that varied in accordance with the oil concentrations (x1), Piper species (x2), age of eggs (x3) and interaction between $x 1: x 2, x 1: x 3$ and $x 1: x 2: x 3$. The data were adjusted to Poisson distribution with a $\log$ link function, and when they were significant they were analyzed with the Kruskal-Wallis test (Package agricolae) using the R-Core Team software (2014). Lethal concentrations causing $50 \%$ mortality of the eggs $\left(\mathrm{LC}_{50}\right)$ were calculated by Probit analysis (Finney, 1971) using Statistica software (version 7).

\section{RESULTS AND DISCUSSION}

In insects, the egg stage is probably the least studied in terms of its susceptibility to chemical control, and the few studies that assessed the vulnerability of eggs were often reported by accident, arising from the application of insecticides to other developmental phases of insects (Smith; Salkeld, 1966). Both nymphs and adults of $T$. limbativentris usually live hidden among the stalks of rice plants. This characteristic makes the contact of insecticides with the insects difficult, and consequently the eggs are more exposed to the treatments making them the most effective way to control this pest. Eggs are often laid on rice leaves and are exposed for a long time in the environment because the egg stage of $T$. limbativentris has a mean embrionary period of seven days (Botton et al. 1996). For this reason, we evaluated the effect of EOs of leaves from five Piperaceae species on rice stem insect eggs.

In our study was verified that the hatching of $T$. limbativentris nymphs varied significantly as a function of all individual factors and for all interactions between factors (Table 1). For better understanding, the results will be presented and discussed considering the effects of different oil concentrations for each Piper isolated, of each concentration between all species evaluated, of individual Piperaceae species and of age of eggs (Figures 1, 2 and 3).

Piper aduncum - With eggs of 24 and 48 hours old (HO), P. aduncum oil caused a statistically significant reduction in hatching only at higher concentrations; hatching was reduced up to $97 \%$. For eggs near hatching ( 72 and $96 \mathrm{HO}$ ) the oil concentrations greater than $0.25 \%$ produced statistically significant reductions in hatching in relation to the control treatments. The toxicity of the $4 \%$ concentration equally affected the hatching of nymphs among the ages of eggs evaluated (hatching smaller than 24\%). In general, all concentrations were significantly more toxic for eggs of 48, 72 and $96 \mathrm{HO}$ than at $24 \mathrm{HO}$ (Figure 1). The differences observed in the hatching of nymphs after application of $P$. aduncum oil can be explained by the amounts of the major constituent chemicals found in this species (dilapiolle, $\mathrm{z}$-carpacin and myristicin) (Figure 2).

Table 1: Summary of generalized linear model and deviance analysis to show (or not) differ in factors and your interactions.

\begin{tabular}{|c|c|c|c|}
\hline Factors & d.f. & $x^{2}$ & P-value \\
\hline Oil concentrations & $5 ; 1194$ & 959.18 & $<0.001$ \\
\hline Piper species & $4 ; 1190$ & 111.56 & $<0.001$ \\
\hline Age of eggs & $3 ; 1187$ & 55.94 & $<0.001$ \\
\hline $\begin{array}{l}\text { Oil concentrations: } \\
\text { Piper species }\end{array}$ & $20 ; 1167$ & 271.44 & $<0.001$ \\
\hline $\begin{array}{l}\text { Oil concentrations: } \\
\text { Age of eggs }\end{array}$ & $15 ; 1152$ & 79.18 & $<0.001$ \\
\hline Piper species: Age of eggs & $12 ; 1140$ & 192.72 & $<0.001$ \\
\hline $\begin{array}{l}\text { Oil concentrations: } \\
\text { Piper species: Age of eggs }\end{array}$ & $60 ; 1080$ & 463.14 & $<0.001$ \\
\hline
\end{tabular}

Piper malacophyllum - The majority of oil concentrations from $P$. malacophyllum allowed hatching rates above $50 \%$ except for the highest concentration in eggs $24 \mathrm{HO}$ and in concentrations between 0.5 and $2 \%$ in eggs $96 \mathrm{HO}$ (Figure 1). These results may be related to the main compounds found in leaf oil from P. malacophyllum, which are different from those found in $P$. aduncum, especially $\alpha$-bulnesene $(20.7 \%)$ and trans- $\beta$-guaiene (15.8\%) (Figure 2).

Piper marginatum - Oil in the concentrations of 2 and $4 \%$ showed greater impact on $T$. limbativentris eggs of all ages with percentages of hatching inhibition reaching $99 \%$. Concentrations below $1 \%$ did not differ statistically from control treatments except for eggs 24 and $96 \mathrm{HO}$. In treatments on eggs 48 and $72 \mathrm{HO}$ the concentrations of $0.25 \%$ and $0.5 \%$, respectively, produced statistically significant reductions in hatching of nymphs in relation to the control treatments (Figure 1). The differences observed between treatments are possibly related to the main chemical compounds present in the leaves, such as prezizane $(7.6 \%)$, E-isolemicin $(10.0 \%)$, spathulenol $(9.3 \%)$ and longifolene $(2.8 \%)$ (Figure 2). 

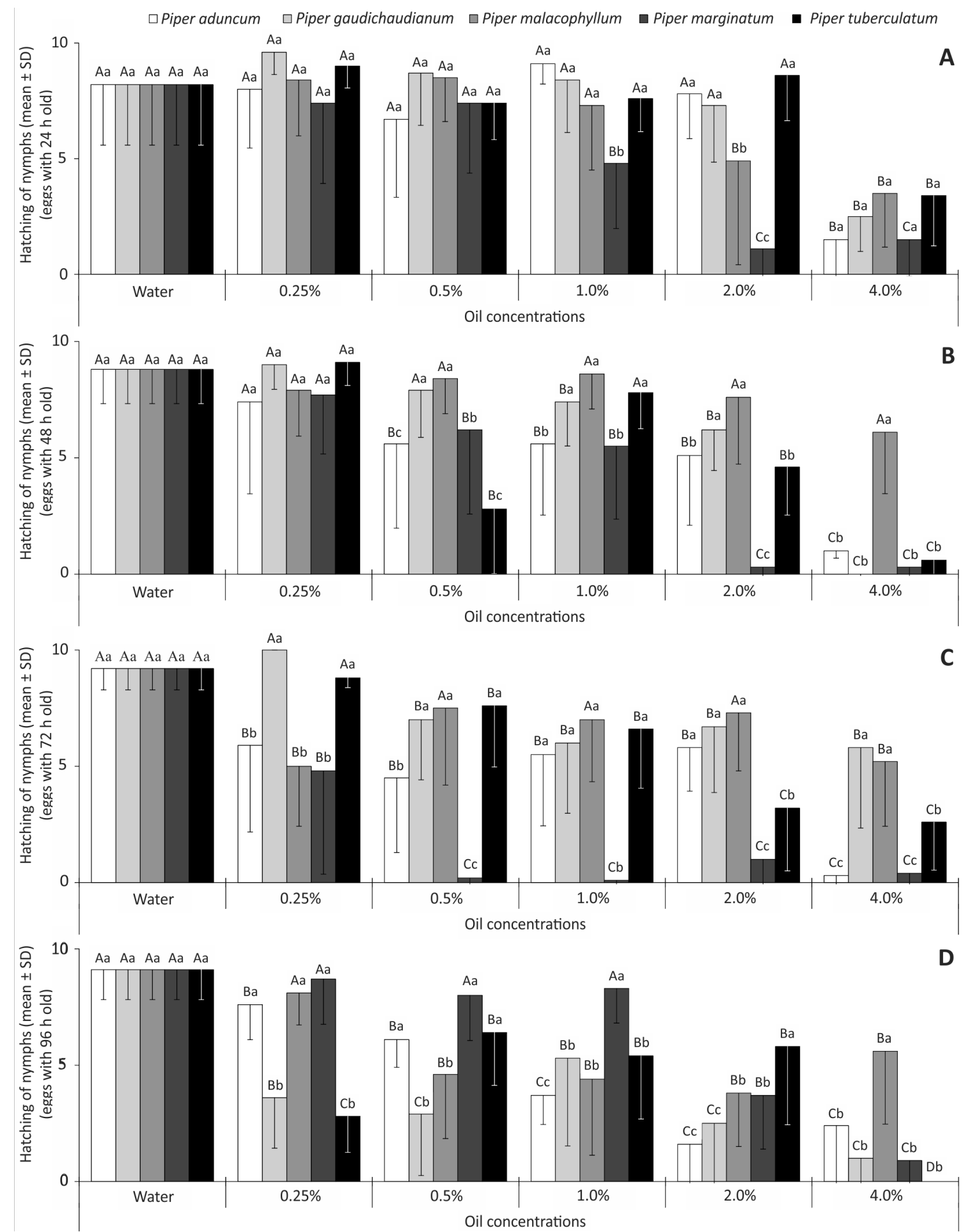

Figure 1: Mean number ( \pm standard deviation) of hatching of Tibraca limbativentris nymphs after immersion of 24, 48, 72 and $96 \mathrm{~h}$ old $(\mathrm{HO})$ egg masses in different concentrations of essential oils from five Piper species. Capital letters compares the values for same species between different concentrations (bars with the same color). Lowercase letters compare the values to different Piper species within the same concentration (different color bars). 

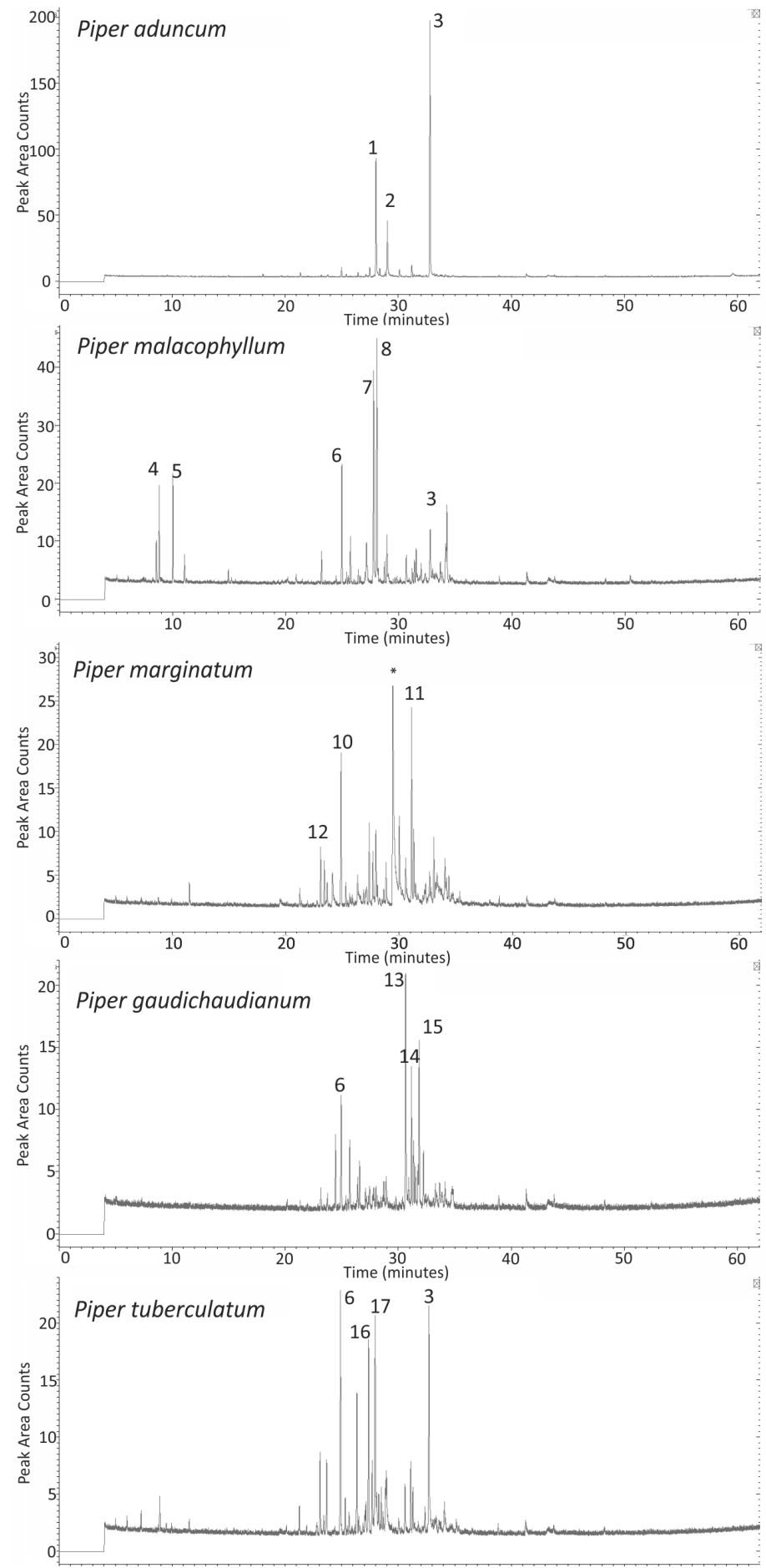

Figure 2: Major chemical constituents present in essential oils of leaves from Piper aduncum, Piper gaudichaudianum, Piper malacophyllum, Piper marginatum and Piper tuberculatum. 1) myristicin; 2) z-carpacin; 3) dilapiolle; 4) o-cymene; 5) y-terpinene; 6) a-guaiene; 7) trans- $\beta$-guaiene; 8) a-bulnesene; 9) $\beta$-cubebene; 10) prezizane; 11) spathulenol; 12) longifolene; 13) longipinanol; 14) globulol; 15) 5-epi-7-epi-a-eudesmol; 16) 9-epi-E-cariofilene and 17) trans-muurola4(14).5-diene. *Phythalate. 

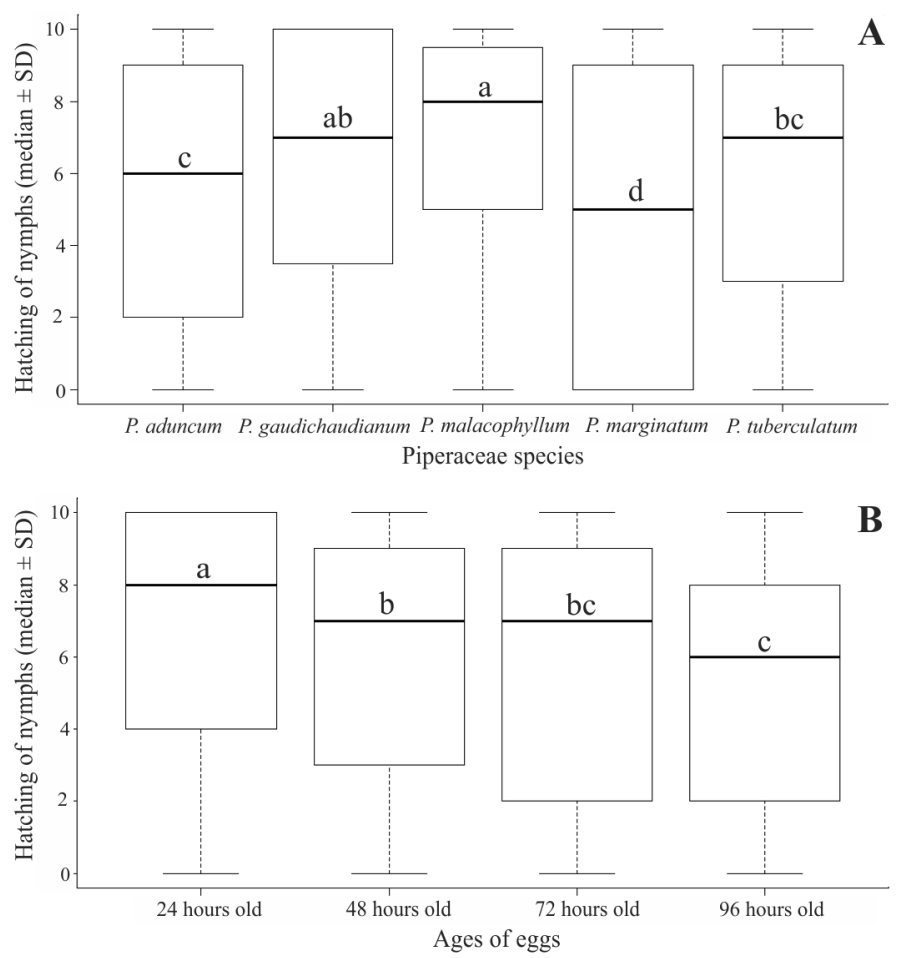

Figure 3: Box-plots diagram showing the hatching of Tibraca limbativentris nymphs after immersion of egg masses in essential oils from Piperaceae species (a), and in egg masses with different ages (b). Box-plots followed the same letters do not differ statistically.

Piper gaudichaudianum - Oil presented ovicidal activity with inhibition percentages that increased with egg age, reaching $90 \%$ in eggs $96 \mathrm{HO}$. The concentration of $4 \%$ inhibited the hatching of more than $75 \%$ of nymphs in eggs of all ages, except in $72 \mathrm{HO}$ eggs, in which more than $58 \%$ of nymphs hatched in all tested concentrations. Egg masses $96 \mathrm{HO}$ tended to be more susceptible to treatment than younger eggs (Figure 1). These differences among treatments for $P$. gaudichaudianum are possibly related to the large amount of longipinanol (19.1\%), globulol (10.3\%), 5-epi-7-epi- $\alpha$-eudesmol (13.3\%) and $\alpha$-guaiene $(8.3 \%)$ found in the leaves (Figure 2 ).

Piper tuberculatum - Oil in general had little effect on $T$. limbativentris eggs with hatching of nymphs almost always greater than $50 \%$, except for eggs $24 \mathrm{HO}$ (concentration of 4\%), $48 \mathrm{HO}$ (concentrations of $0.5,2$ and 4\%), $72 \mathrm{HO}$ ( 2 and $4 \%$ concentration) and $96 \mathrm{HO}$ (concentration 0.25 and $4 \%$ ) which showed significant differences when compared to the control treatments. There was no relationship between toxicity and age of eggs at the time of treatment (Figure 1). These differences among the concentrations of $P$. tuberculatum oil are possibly related to the diversity of compounds found and also to the amount of each component, especially for myristicin (15.5\%), dilapiolle (13.8\%), $\alpha$-guaiene (13.0\%), 9-epi-e-cariofilene (7.1\%) and trans-4-muurola(14).5diene $(9.9 \%$ ) (Figure 2$)$.

To consider a product as ovicidal, it should inhibit hatching by at least $75 \%$ (Picollo; Zerba, 1997). The oils of the five Piperaceae species studied were able to stop the development of $T$. limbativentris embryos still inside the egg (Figure 1). There is little information in the literature on the ovicidal action of essential plant oils or any other type of insecticide, including conventional chemicals, for the control of Pentatomidae pests.

\section{Comparison of the essential oil from leaves of five Piper species and age of eggs}

Among the few studies that reported the ovicidal effect on Pentatomidae eggs, only two of them evaluated the toxicity of EOs and few studies tested the effects of chemical insecticides or biopesticides on pentatomid eggs (Anandhi; Pillai, 2006; Cutler et al., 2006; Cutler; Scott-Dupree, 2007; González et al., 2011). Some 
research evaluated the ovicidal and nymphicidal effects from different plants and pyrethroids on stink bug eggs of the Reduviidae and Pentatomidae families (Carneiro; Pereira; Galbiati, 2011; Krinski; Massaroli, 2014; Krinski; Massaroli; Machado, 2014; Laurent et al. 1997; Rodrigues et al. 2002). Besides the use of EOs, some studies also reported the ovicidal activity of algae and plant extracts (Piton et al. 2014; Sahayaraj; Kalidas, 2011).

Our data show that the hatching of nymphs varied as a function of Piper species and also as a function of age of eggs (Table 1). Piper marginatum oil provided results consistently higher than the other species in eggs of all ages, showing ovicidal activity at a concentration of $0.5 \%$. Piper gaudichaudianum, $P$. malacophyllum and $P$. tuberculatum showed an effect on T. limbativentris eggs only in some concentrations and ages of eggs (inhibited hatching of at least $75 \%$ of the nymphs). This same pattern was observed for $P$. aduncum oil in all ages of the eggs (Figure 3a). Eggs near hatching (96 HO) tended to be more susceptible to the oils of Piper species than younger eggs (Figure 3b).

Although studies that evaluate the ovicidal activity of plants are scarce, some authors report the inefficiency of some plants as ovicides (Parra-Henao; Pajón; Torres, 2007; Valladares et al. 1999). The results obtained by the aforementioned authors may be related to the age of eggs used in the experiments (although the age of the eggs is not mentioned in these studies), as our findings showed a higher rate of reactivity to the EOs in older $T$. limbativentris eggs than in younger ones. This leads us to three hypotheses regarding the possible cause of the higher rate of embryo mortality in older eggs.

First, EOs cross the chorion of older eggs more easily, coinciding with the period of cuticle formation in the embryo and effect or hinder the formation of this structure. This is reported by some researchers as being an effect of benzoylurea on the embryos (Retnakaran; Wrigth, 1987). In addition, older egg masses may contain a lower amount of wax on the eggs. This enables the entry of a larger quantity of EOs into the egg through the micropyle in the chorion and consequently, the penetration of greater amounts of potentially toxic chemicals into the embryo (Beament, 1989; Smith; Salkeld, 1966). The micropyles have been identified as being the main point of penetration of chemicals in Reduviidae eggs of Rhodnius prolixus Stål, 1859 (Reduviidae) (Beament, 1948; 1949).

Secondly, if we consider that the diffusion of oxygen through the chorion has an important role in respiration of the embryo, as reported by Hinton (1981), we can infer that the embryos present in younger eggs require less oxygen at this stage, or are less affected by deoxygenation after the application of EOs, which due to its volatility would be rapidly degraded in the environment. Meanwhile, more developed embryos need more oxygen, and thus, may be more affected by deoxygenation due to micropyle obstruction caused by oil application. This characteristic has been reported after the use of petroleum oils, which interfere in gas exchange between the chorion and the embryo of the stink bug Oncopeltus fasciatus (Dallas, 1852) (Lygaeidae). When pseudo-micropyles were covered with this oil it proved to be lethal for the embryos (Fiori et al., 1963).

Thirdly, due to the high volatility of EOs, when the application was carried out in younger eggs of $T$. limbativentris it is possible that the volatile compounds were quickly lost in the environment, and embryos that were still in the early stages of development were able to survive during the embryonic period. On the other hand, when the oils were applied to older egg masses, the embryos, although already more developed, were unable to detoxify, or became weak and failed to break the chorion, thus dying inside the eggs. In addition, the oils may have left the chorion more rigid, which may also have hindered the hatching of nymphs.

\section{Lethal concentrations}

The lethal concentrations $\left(\mathrm{LC}_{50}\right)$ almost always showed an inverse relationship between concentration and time because the oils applied on older eggs showed lower $\mathrm{LC}_{50}$. Comparing the $\mathrm{LC}_{50}$ of leaf oils among the Piper species we observed that lower concentrations occurred in egg masses of up to $72 \mathrm{HO}$ for $P$. marginatum oil, which was five to 15 times more efficient than the other leaf oils (Table 2). In addition, P. aduncum oil was more efficient in egg masses with more than 48 hours of development, always with an $\mathrm{LC}_{50}$ lower than $1.5 \%$. A similar pattern was observed for the $\mathrm{LC}_{50}$ of $P$. tuberculatum oil for eggs 48 and $96 \mathrm{HO}$. The $\mathrm{LC}_{50}$ of other leaf oils were almost always higher than $2.0 \%$, with the exception of $P$. gaudichaudianum oil applied on egg masses of $96 \mathrm{HO}$, which had the second lowest $\operatorname{LC}_{50}(0.594 \%)$ among all EOs tested, being five times more efficient than other oils applied on egg masses of this age (Table 2).

The ovicidal activity and lethal concentrations observed in our study may be related to the potential toxicity of the main chemical components found in all Piper species, and also by synergistic action among these compounds. In P. aduncum oil, the chemicals with the greatest proportions were the dilapiolle and myristicin, $53.6 \%$ and $24.3 \%$ respectively, and the inhibition of 
hatching nymphs after oil application might have been due to a synergistic effect of these two compounds present in leaf oil (Figure 1). The same pattern of dilapiolle and myristicin quantities found for $P$. aduncum in this study has been found in other Piperaceae species, showing that other species can be used as a source of these compounds, which are considered phyto-insecticides (Martins et al. 1998; Morais et al. 2007). Myristicin has been found in other Piperaceae species which showed activity against Isoptera and Lepidoptera (Chieng; Assim; Fasihuddin, 2008; Srivastava et al. 2001).

The compounds bulnesene- $\alpha$, trans- $\beta$-guaiene and $\alpha$-guaiene were the major compounds present in $P$. malacophyllum oil (Figure 1). Some studies showed the insecticidal activity and repellent activity of these compounds, but they were derived from other plant families (Valerianaceae and Lamiaceae) and used against insect pests of stored food (Psocoptera, Liposcelidae) and urban ants (Formicidae) (Albuquerque et al., 2013; Liu; Zhou; Liu, 2013).

The inhibition of hatching nymphs observed between treatments of $P$. marginatum oil may also be related to the main chemical compounds such as prezizane, E-isolemicin and spathulenol (Figure 1). Given the findings of other studies that verified the bioactivity of other plants also containing spathulenol, it is likely that this substance is the main toxic compound of $P$. marginatum. A previous study demonstrated its anti-termite effect and larvicidal activity in mosquitoes (Mathew; Thoppil, 2011). These results show that this compound has great potential for use as a phytoinsecticide, especially when we consider that the spathulenol has been found in several species of Piper (Vargas et al., 2004; Andrade et al., 2006; Facundo; Rezende; Pinto, 2006; Mesquita et al., 2005; Rahman et al., 2011).

The results of $P$. gaudichaudianum oil are related to the large quantity of longipinanol, globulol, 5-epi-7-epi$\alpha$-eudesmol and $\alpha$-guaiene (Figure 1). This information corroborates data from other studies that found longipinanol in P. aduncum (Oliveira et al., 2006) and analogous to 5-epi7-epi- $\alpha$-eudesmol in several Piper species (Abreu et al., 2005; Mesquita et al., 2005; Potzernheim; Bizzo; Vieira, 2006; Santos et al., 2001). The $\alpha$-guaiene compound was found in Piper hispidum Kunth. (Machado et al., 1994) and globulol in Piper fulvescens C. Dc., and Piper manausense Yunck (Andrade et al., 2005; Vila et al., 2001). Piper tuberculatum oil showed great amounts of myristicin and $\alpha$-guaiene, and as previously mentioned, these compounds have also been found in P. aduncum and P. malacophyllum oils, respectively (Figure 1).

However, field and semi-field studies must be done in order to verify if the same pattern of results obtained in laboratory studies are maintained in the field both for T. limbativentris and for other insect pests found in rice and other food crops (Albuquerque, 1993; Krinski; Pelissari, 2012; Krinski; Favetti; Butnariu, 2012; Krinski, 2013; Krinski; Foerster; Grazia, 2015). We observed that the EOs that caused a larger percentage of inhibition of hatching nymphs of $T$. limbativentris were extracted from $P$. marginatum, a species that is not well known phytochemically. Considering these findings, we highlight the use of EOs from the leaves of different Piper species for

Table 2: Lethal concentrations of essential oils from leaves of five Piper species to make unviable $50 \%\left(\mathrm{LC}_{50}\right)$ of Tibraca limbativentris eggs with different ages.

\begin{tabular}{cccccc}
\hline \multirow{2}{*}{$\begin{array}{c}\text { Piper species/Lethal Concentration } \\
\text { 24 hours }\end{array}$} & \multicolumn{5}{c}{ Age of eggs* } \\
\cline { 3 - 6 } Piper aduncum & $\mathrm{LC}_{50}$ & 2.499 & 1.506 & 1.402 & 1.381 \\
& ic & $2.421-2.577$ & $1.401-1.610$ & $1.324-1.480$ & $1.315-1.446$ \\
\hline \multirow{2}{*}{ Piper gaudichaudianum } & $\mathrm{LC}_{50}$ & 2.815 & 2.383 & 4.243 & 0.594 \\
& ic & $2.659-2.971$ & $2.302-2.464$ & $4.086-4.401$ & $0.466-0.723$ \\
\hline \multirow{2}{*}{ Piper malacophyllum } & $\mathrm{LC}_{50}$ & 2.628 & 6.073 & 4.917 & 2.744 \\
& ic & $2.554-2.702$ & $5.819-6.327$ & $4.483-5.001$ & $2.726-2.762$ \\
\hline \multirow{2}{*}{ Piper marginatum } & $\mathrm{LC}_{50}$ & 1.357 & 1.220 & 0.316 & 1.968 \\
& ic & $1.252-1.462$ & $0.923-1.516$ & $0.280-0.913$ & $1.904-2.032$ \\
\hline \multirow{2}{*}{ Piper tuberculatum } & $\mathrm{LC}_{50}$ & 3.388 & 1.576 & 2.086 & 1.221 \\
& ic & $2.554-2.702$ & $3.248-3.528$ & $1.508-1.644$ & $2.047-2.125$ \\
\hline
\end{tabular}

*evaluation made 240 Hours After Immersion of Eggs (HAIE) in the essential oils; ic: interval confidence. 
application as a biorational and organic phyto-insecticide. Due to the ease of obtaining this part of the plant, which can be extracted in a non-destructive manner, and because of the great amount of leaves that the plant has, its leaf recovery capacity is high, as observed in Piperaceae (Riva et al., 2011).

Nonetheless, more studies should be conducted to compare the effect of oils obtained from other plant parts, including inflorescences and branches (stems) from the Piper species used in this study as well as other species with a wide geographical distribution (Fazolin et al., 2007; Ghosh et al., 2014; Lima et al., 2009; Parmar et al., 1997; Santos et al., 2010), to verify whether this ovicidal pattern remains constant. In addition, bioassays should be conducted to test the effect of various EOs on egg parasitoids of insect pests (Favetti et al., 2013; Krinski; Pelissari, 2012; Krinski; Favetti; Butnariu, 2012; Krinski, 2013; Martins; Krinski, 2016; Turchen et al., 2015; Zachrisson; Costa; Bernal, 2014; Zachrisson et al., 2014), since research to verify the selectivity of extracts or EOs of plants on natural enemies are scarce and almost non-existent (Turchen et al., 2014).

It is recognized that natural products from plants are promising sources for the bioprospection of new molecules with potential application in the production of new phyto-chemicals. In recent years the plants considered phyto-insecticides have been the focus of interest of chemists and biologists due to their structural complexity, power and selectivity, as already observed with pyrethrum, one of the most important botanical insecticides to appear in the last two centuries (Isman, 2000). This has also been observed with other chemical compounds such as rotenone, ryanodina, veratridine, azadirachtin, active ingredients from timbó (Lonchocarpus utilis), ryania (Ryania speciosa), sabadilla (Schoenocaulon officinale) and neem (Azadirachta indica), which have been widely used due to their effectiveness and low toxicity to mammals. In recent years, most studies with insecticide plants (green insecticides) have been conducted with neem seeds (Casida; Quistad, 1998; Isman, 2000). There have been few studies concerning other plant groups, such as Piperaceae, even though our study and several others found them to be a rich source of promising molecules for insect control. Thus, there is a clear need to explore the potential for bioprospection studies, such as the isolation of the main phyto-insecticide compounds from the Piperaceae species, and subsequent synthesis of these substances, which may even add value to native plant species.

\section{CONCLUSIONS}

The main chemical compounds found in the Piper species used in our study demonstrated the great potential that this plant family has as a phyto-insecticide, especially in their leaves, which showed excellent results to inhibit the hatching of $T$. limbativentris nymphs. This study showed that the susceptibility of eggs this stink bug may change during embryonic development, and the relationship between age and egg susceptibility may vary according to the different oils from the Piper species used. In addition, the Piperaceae species used in our study were collected from several regions in Brazil, demonstrating that species found in different locations may be used for integrated pest management. Thus, the re-evaluation of strategies and insect control tactics has become a central concern of many researchers. This concern arises from the failure of control programs that are based strictly on chemical control. At the same time, there is a growing interest in organic, pesticidefree products, as well as raised awareness by producers and consumers, encouraging environmentally friendly attitudes. All of these aspects should encourage the search for alternative products that do not harm the environment.

\section{ACKNOWLEDGMENTS}

The authors acknowledge the Conselho Nacional de Desenvolvimento Científico e Tecnológico (CNPq) and the Coordenação de Aperfeiçoamento de Pessoal de Nível Superior (CAPES), for providing scholarship to the first author (CNPq - Proc.: 141243/2012-0 and CAPES - Proc.: 939980). We thank also Dr. Cícero Dechamps of Plant Ecophysiology Laboratory from Federal University of Paraná (UFPR), Dr. José Alexandre Freitas Barrigossi from Brazilian Agricultural Research Corporation/ National Center for Rice and Bean Research (EMBRAPA/ CNPAF) and Dr. Clécio Sousa Ramos, from Department of Molecular Sciences, Rural Federal University of Pernambuco (UFRPE), for their assistenced and support during this research.

\section{REFERENCES}

ALBUQUERQUE, E. L. D. et al. Insecticidal and repellence activity of the essential oil of Pogostemon cablin against urban ants species. Acta Tropica. 127(3):181-186, 2013.

ALBUQUERQUE, G. S. Planting time as a tactic to manage the small rice stink bug, Oebalus poecilus (Hemiptera, Pentatomidae), in Rio Grande do Sul, Brazil. Crop Protection. 12(8):627-630, 1993. 
ABREU, A. M. et al. Volatile constituents of Piperaceae from Santa Catarina, Brazil - Essential oil composition of Piper cernuum Vell. and Peperomia emarginella (Sw.) C. DC. Journal of Essential Oil Research. 17(3):286288, 2005.

ADAMS, R. P. Identification of essential oil components by Gas chromatography/Mass Spectroscopy. Allured Publishing Corporation. 2007, 804p.

ANANDHI, P.; PILLAI, M. A. K. Ovicidal activity of some insecticides against Scotinophara coaractata (Fab.) (Hemiptera: Pentatomidae) on rice. Journal of Entomological Research. 30(1):65-66, 2006.

ANDRADE, E. H. A. et al. Essential oil composition of Piper cyrtopodon (Miq.) C. DC. Journal of Essential Oil Bearing Plants. 9(1):53-59, 2006.

ANDRADE, E. H. A. et al. Essential oil composition of Piper manausense Yuncker. Journal of Essential Oil Bearing Plants. 8(3):295-299, 2005.

BARBOSA, Q. P. S. et al. Chemical composition, circadian rhythm and antibacterial activity of essential oils of Piper divaricatum: A new source of safrole. Química Nova. 35(9):1806-1808, 2012.

BEAMENT, J. John Hull Grundy lecture: Eggs - The Neglected Insects. Journal of the Royal Army Medical Corps. 135(2):49-56, 1989.

BEAMENT, J. W. L. The penetration of insect egg shells: I. Penetration of the chorion of Rhodius prolixus Stål. Bulletin of Entomological Research. 39(3):359-383, 1948.

BEAMENT, J. W. L. The penetration of insect egg shells II. The properties and permeability of subchoral membranes during development of Rhodnius prolixus Still. Bulletin of Entomological Research. 39(4):467-488, 1949.

BOTTON, M. et al. Biologia de Tibraca limbativentris Stål, 1860 em plantas de arroz. Anais da Sociedade Entomológica do Brasil. 25(1):21-26, 1996.

CARNEIRO, A. P.; PEREIRA, M. J. B.; GALBIATI, C. Biocidal effect of the Annona coriacea Mart 1841 on eggs and nymphs of the vector Rhodnius neglectus Lent 1954. Neotropical Biology and Conservation. 6(2):131-136, 2011.

CASIDA, J. E.; QUISTAD, G. B. Golden age of insecticide research: Past, present, or future? Annual Review of Entomology. 43(1):1-16, 1998.

CHIENG, T. C.; ASSIM, Z. B.; FASIHUDDIN, B. A. Toxicity and antitermite activities of the essential oils from Piper sarmentosum. Malaysian Journal of Analytical Sciences. 12(1):234-239, 2008.

COSTA, E. L. N.; SILVA, R. F. P.; FIUZA, L. M. Efeitos, aplicações e limitações de extratos de plantas inseticidas. Acta Biologica Leopoldensia. 26(2):173-185, 2004.

CUTLER, G. C.; SCOTT-DUPREE, C. D. Novaluron: Prospects and limitations in insect pest management. Pest Technology. 1(1):38-46, 2007.

CUTLER, G. C. et al. Toxicity of the insect growth regulator novaluron to the non-target predatory bug Podisus maculiventris (Heteroptera: Pentatomidae). Biological Control. 38(2):196-204, 2006.

ESTRELA, J. L. V. et al. Toxicity of essential oils of Piper aduncum and Piper hispidinervum against Sitophilus zeamais. Pesquisa Agropecuária Brasileira. 41(2):217-222, 2006.

FACUNDO, V. A.; REZENDE, C. M.; PINTO, A. Essential oil of Piper carniconnectivum C.CD. leaves and stems. Journal of Essential Oil Research. 18(3):296-297, 2006.

FAVETTI, B. M. et al. Egg parasitoids of Edessa meditabunda (Fabricius) (Pentatomidae) in lettuce crop. Revista Brasileira de Entomologia. 57(2):236-237, 2013.

FAZOLIN, M. et al. Insecticidal properties of essential oils of Piper hispidinervum C. DC.; Piper aduncum L. and Tanaecium nocturnum (Barb. Rodr.) Bur. \& K. Shum against Tenebrio molitor L., 1758. Ciência e Agrotecnologia. 31(1):113-120, 2007.

FINNEY, D. J. Probit Analysis. New York: University Press, Cambridge, 1971, 333p.

FIORI, B.J.; SMITH, E.H; CHAPMAN, P.J. Some factors influencing the ovicidal effectiveness of saturated petroleum oils and synthetic isoparaffins. Journal of Economic Entomology. 56(6):885-888-1963.

GHOSH, R. et al. An overview of various Piper species for their biological activities. International Journal of Pharmaceutical Sciences Review and Research. 3(1):6775, 2014.

GONZÁLEZ, J. O. W. et al. Composition and biological activity of essential oils from Labiatae against Nezara viridula (Hemiptera: Pentatomidae) soybean pest. Pest Management Science. 67(8):948-955, 2011.

HINTON, H. E. Biology of insect eggs in three volumes. Oxford: Pergamon Press. 1981, 1125p.

ISMAN, M. B. Plant essential oils for pest and disease management. Crop Protection. 19(8-10):603-608, 2000. 
KRINSKI, D.; FOERSTER, L. A. Damage by Tibraca limbativentris Stål (Pentatomidae) to Upland Rice Cultivated in Amazon Rainforest Region (Brazil) at Different Growth Stages. Neotropical Entomology, 10.1007/s13744-016-0435-5, 2016.

KRINSKI, D.; MASSAROLI, A. Nymphicidal effect of vegetal extracts of Annona mucosa and Annona crassiflora (Magnoliales, Annonaceae) against rice stalk stink bug, Tibraca limbativentris (Hemiptera, Pentatomidae). Revista Brasileira de Fruticultura. 36(n.spe1):217224, 2014.

KRINSKI, D.; MASSAROLI, A.; MACHADO, M. Insecticidal potential of the Annonaceae family plants. Revista Brasileira de Fruticultura. 36(n.spe1):225-242, 2014.

KRINSKI, D. First report of phytophagous stink bug in chicory crop. Ciência Rural. 43(1):42-44 2013.

KRINSKI, D.; FAVETTI, B. M.; BUTNARIU, A. R. First record of Edessa meditabunda (F.) on lettuce in Mato Grosso State, Brazil. Neotropical Entomology. 41(1):79-80, 2012.

KRINSKI, D.; FOERSTER L. A.; GRAZIA, J. Hypatropis inermis (Hemiptera, Pentatomidae): First report on rice crop. Revista Brasileira de Entomologia. 59(1):12-13, 2015.

KRINSKI, D.; PELISSARI, T. D. Occurrence of the stinkbug Edessa meditabunda F. (Pentatomidae) in differents cultivars of lettuce Lactuca sativa L. (Asteraceae). Bioscience Journal. 28(4):654-659, 2012.

LAURENT, D. et al. Insecticidal activity of essential oils on Triatoma infestans. Phytotherapy Research. 11(4):283290, 1997.

LIMA, R. K. et al. Insecticidal activity of long-pepper essential oil (Piper hispidinervum C. DC.) on fall armyworm Spodoptera frugiperda (J. E. Smith, 1797) (Lepidoptera: Noctuidae). Acta Amazonica. 39(2):377-382, 2009.

LIU, X. C.; ZHOU, L.; LIU, Z. L. Identification of insecticidal constituents from the essential oil of Valeriana jatamansi Jones against Liposcelis bostrychophila Badonnel. Journal of Chemistry. 2013(2013):1-6, 2013.

MACHADO, S. M. F. et al. Leaf oils of two Brazilian Piper species: Piper arboreum Aublet var. latifolium (C.DC.) Yuncker and Piper hispidum Sw. Journal of Essential Oil Research. 6(6):643-644, 1994.

MARTINS, A. L.; KRINSKI, D. First record of the parasitoid Gonatopus flavipes Olmi, 1984 (Hymenoptera, Dryinidae) in Brazil's Amazon forest. Journal of Hymenoptera Research. 50:191-196, 2016.
MARTINS, J. F. S.; GRÜTZMACHER, A. D.; CUNHA, U. S. Descrição e manejo integrado de insetos-pragas em arroz irrigado. In: GOMES, A. S.; MAGALHÃES-JUNIOR, A. M. Arroz irrigado no sul do Brasil. Brasília: Embrapa Clima Temperado/ Embrapa Informação Tecnológica, 2004, p.635-675.

MARTINS, A. P. et al. Essential oils from four Piper species. Phytochemistry. 49(7):2019-2023, 1998.

MATHEW, J.; THOPPIL, J. E. Chemical composition and mosquito larvicidal activities of Salvia essential oils. Pharmaceutical Biology. 49(5):456-463, 2011.

MESQUITA J. M. O. et al. Comparative study of the essential oils of some species of Piperaceae. Revista Brasileira de Farmacognosia. 15(1):6-12 2005.

MORAIS, S. M. et al. Chemical composition and larvicidal activity of essential oils from Piper species. Biochemical Systematics and Ecology. 35(10):670-675, 2007.

OLIVEIRA, J. C. S. et al. Volatile constituents of the leaf oils of Piper aduncum L. from different regions of Pernambuco (Northeast of Brazil). Journal of Essential Oil Research. 18(5):557-559, 2006.

OLSON, S. An analysis of the biopesticide market now and where it is going. Outlooks on Pest Management. 26(5):203-206, 2015.

PARMAR, V. S. et al. Phytochemistry of the genus Piper. Phytochemistry. 46(4):591-673, 1997.

PARRA-HENAO, G.; PAJÓN, C. M. G.; TORRES, J. M. C. Actividad insecticida de extractos vegetales sobre Rhodnius prolixus y Rhodnius pallescens (Hemiptera: Reduviidae). Boletin de Malariologia y Salud Ambiental. 47(1):125-137 2007.

PETROSKI, R. J.; STANLEY, D. W. Natural compounds for pest and weed control. Journal of Agricultural and Food Chemistry. 57(18):8171-8179, 2009.

PICOLLO, M. I.; ZERBA, E. Embryogenesis. In: CARCAVALLO, R. U. et al. Atlas dos vetores da Doença de Chagas nas Américas. Rio de Janeiro: Fiocruz, 1997, p.265-270.

PITON, L. P. et al. Natural insecticide based-leaves extract of Piper aduncum (Piperaceae) in the control of stink bug brown soybean. Ciência Rural. 44(11):1915-1920, 2014.

POTZERNHEIM, M. C. L.; BIZZO, H. R.; VIEIRA, R. F. Analysis of the essential oil of three species of Piper collected in the region of the Distrito Federal (Cerrado - Brazilian Savannah) and comparison with oils of plants from region of Paraty, State of Rio de Janeiro (Atlantic Rain Forest). Revista Brasileira de Farmacognosia. 16(2):246-251, 2006. 
R CORE TEAM. R: A language and environment for statistical computing. R Foundation for Statistical. Computing, Vienna, Austria. 2014. Available in: <http://www.R-project. org>. Access in: May, 10, 2016.

RAHMAN, A. et al. Potential roles of essential oil and extracts of Piper chaba Hunter to inhibit Listeria monocytogenes. Records of Natural Products. 5(3):228-237, 2011.

RAMPELOTTI, F. T. et al. Patogenicity of Metarhizium anisopliae (Metsch.) Sorokin on the phases of the development of Tibraca limbativentris Stål (Hemiptera: Pentatomidae) under laboratory conditions. Arquivos do Instituto Biológico. 74(2):141-148, 2007.

RAMPELOTTI-FERREIRA, F. T. et al. Selectivity of chemical pesticides used in rice irrigated crop at fungus Metarhizium anisopliae, microbial control agent of Tibraca limbativentris. Ciência Rural. 40(4):745-751, 2010.

RETNAKARAN, A.; WRIGTH, J. E. Control of insect pests with benzoylphenyl ureas In: WRIGHT, J. E.; RETNAKARAN, A. Chitin and benzoyphenyl ureas. Dordrecht: Dr. W. Junk Publications, 1987, p.205-288.

RIVA, D. et al. Adaptation studies of Piper hispidinervum C. DC. (long pepper) species in Itajaí Valley - SC, by the chemical composition of essential oil obtained by microwave and traditional hydrodistillation. Acta Amazonica. 41(2):297302, 2011.

RODRIGUES, V. L. C. C. et al. Triatomine: Ovicidal action of some pyretroids. Revista da Sociedade Brasileira de Medicina Tropical. 35(2):237-241, 2002.

SAHAYARAJ, K. Basic and applied aspects of biopesticides. New Delhi: Springer, 2014, 384 p.

SAHAYARAJ, K.; KALIDAS, S. Evaluation of nymphicidal and ovicidal effect of a seaweed, Padina pavonica (Linn.) (Phaeophyceae) on cotton pest, Dysdercus cingulatus (Fab.). Indian Journal of Geo-Marine Sciences. 40(1):125-129. 2011.

SANTOS, M. R. A. et al. Atividade inseticida do extrato das folhas de Piper hispidum (Piperaceae) sobre a broca-docafé (Hypothenemus hampei). Brazilian Journal of Botany. 33(2):319-324, 2010.

SANTOS, P. R. D. et al. Essential oil analysis of 10 Piperaceae species from the Brazilian Atlantic forest. Phytochemistry. 58(4):547-551, 2001.
SCOTT, I. M. et al. A review of Piper spp. (Piperaceae) phytochemistry, insecticidal activity and mode of action. Phytochemistry Reviews. 7(1):65-75, 2008.

SMITH, E. H.; SALKELD, E. H. The use and action of ovicides. Annual Review of Entomology. 11:331-368, 1966.

SOUZA, J. R. et al. Genetic divergence of rice cultivars for resistance to Tibraca limbativentris Stål (Hemiptera: Pentatomidae). Neotropical Entomology. 38(5):671-676, 2009.

SRIVASTAVA, S. et al. Insecticidal activity of myristicin from Piper mullesua. Pharmaceutical Biology. 39(3):226-229, 2001.

TURCHEN, L. M. et al. Natural parasitism of Hexacladia smithii Ashmead (Hymenoptera: Encyrtidae) on Euschistus heros (F.) (Hemiptera: Pentatomidae): New record from Mato Grosso State, Brazil. Arquivos do Instituto Biológico. 82(1):1-3, 2015.

TURCHEN, L. M. et al. Selectivity of Annona (Annonaceae) extract on egg parasitoid Trissolcus urichi (Hymenoptera: Platygastridae). Revista Colombiana de Entomologia. 40(2):176-180, 2014.

VALLADARES, G. R. et al. Effects of Melia azedarach on Triatoma infestans. Fitoterapia. 70(4):421-424, 1999.

VAN DEN DOOL H.; KRATZ, P. D. A generalization of the retention index system including liner temperature programmed gas-liquid partition chromatography. Journal of Chromatography A. 11:463-467, 1963.

VARGAS, L. et al. Essential oil composition of the leaves and spikes of Piper carpunya Ruíz et Pavón (Piperaceae) from Peru. Journal of Essential Oil Research. 16(2):122-123, 2004.

VILA, R. et al. Chemical composition of the essential oil from the leaves of Piper fulvescens, a plant traditionally used in Paraguay. Journal of Ethnopharmacology. 76(1):105107, 2001.

ZACHRISSON, B.; COSTA, V.; BERNAL, J. Incidencia natual de parasitoides de huevos de Oebalus insularis Stal (Heteroptera: Pentatomidae) en Panamá. Idesia. 32(2):119121, 2014

ZACHRISSON, B. et al. Eggs parasitism of Tibraca limbativentris (Hemiptera: Pentatomidae), in rice (Oryza sativa) in Panamá. Revista Colombiana de Entomología. 40(2):185-186, 2014. 